\title{
Analisis strategi peningkatan daya saing pada UKM Anugrah Mina Lestari
}

\section{Analysis of strategies to increase competitiveness in SMEs Anugrah Mina Lestari}

\author{
Dayang Diah Fidhiani ${ }^{1 *}$ \\ ${ }^{1}$ Program Studi Budidaya Perairan, Sekolah Tinggi Ilmu Perikanan, Malang \\ *Email korespondensi: findhiani30@ gmail.com \\ Informasi Artikel: \\ Dikirim: 03/07/2021; disetujui: 25/08/2021; diterbitkan: 28/09/2021
}

\begin{abstract}
UKM Anugrah Mina Lestari is an UKM that processes milkfish into smoked milkfish products and millennial milkfish brains, which are very popular, especially children and teenagers. Anugrah Mina Lestari UKM in Malang City plays an important role in national economic growth. The purpose of this study was to obtain a strategy to increase the competitiveness of UKM Anugrah Mina Lestari in Malang City. Technical analysis of this research data using the AHP method with the concept of the house model to determine strategies to increase the competitiveness of SMEs Anugrah Mina Lestari in Malang City. The results of the study show that by increasing product variables, improving human resources and marketing institutions can be a strengthening strategy for sustainable competitiveness improvement in Anugrah Mina Lestari SMEs.
\end{abstract}

Keywords: competitiveness, SMEs, the house model

\begin{abstract}
ABSTRAK
UKM Anugrah Mina Lestari merupakan UKM yang mengolah ikan bandengan menjadi produk bandeng asap dan otak-otak bandeng millenial, yang sangat disukai terutama anak-anak serta remaja. UKM Anugrah Mina Lestari di Kota Malang memegang peranan penting dalam pertumbuhan ekonomi nasional. Tujuan penelitian ini adalah mendapatkan strategi peningkatan daya saing UKM Anugrah Mina Lestari di Kota Malang. Teknis analisis data penelitian ini menggunakan metode AHP dengan konsep the house model untuk menentukan strategi peningkatan daya saing UKM Anugrah Mina Lestari di Kota Malang. Hasil penelitian menunjukkan dengan meningkatkan variabel produk, perbaikan SDM dan kelembagaan pemasaran dapat menjadi penguatan strategi peningkatan daya saing yang berkelanjutan pada UKM Anugrah Mina Lestari.
\end{abstract}

Kata Kunci: daya saing, UKM, the house model

\section{PENDAHULUAN}

Daya saing sektor perikanan dan kelautan menjadi salah satu kata kunci dalam pembangunan industri pengolahan hasil perikanan. Daya saing akan meningkat apabila performa industri dapat tumbuh dan berkembang. Selama ini bentuk olahan produksi perikanan dikategorikan dalam 2 kelompok utama yaitu produk olahan
UMKM dan produk olahan industri. Olahan UMKM terdiri dari hasil olahan pindang, asap, asin, pelumatan, fermentasi, dan lainnya, sedangkan kelompok olahan industri di antaranya adalah pembekuan, pengalengan, segar, sashimi dan sebagainya (Boer et al., 2020). UKM mempunyai peran yang semakin penting dalam pertumbuhan ekonomi sebagian besar negara. Pentingnya UKM disadari begitu besar ketika melihat 
ketahanan ekonomi UKM yang begitu besar di beberapa belahan dunia (Kalpande et al., 2015; Purwidianti \& Rahayu, 2017). Kontribusi UKM terhadap lapangan kerja mengurangi kemiskinan membuat ekonomi tumbuh dengan baik (Ayandibu \& Houghton, 2017). UKM juga bisa bertindak sebagai pemasok barang dan jasa untuk perusahaan besar. Sebagian besar UKM telah dapat bergerak secara dinamis, inovatif, efisien dan ukurannya yang kecil memungkinkan fleksibilitas, umpan balik langsung, rantai pengambilan keputusan pendek, pemahaman yang lebih baik dan respon yang lebih cepat terhadap kebutuhan pelanggan (Idar \& Mahmood, 2011). Pendapat Wiesner dan Millett (2012) menyatakan bahwa terlepas dari kontribusi yang kuat, UKM tetap rentan terhadap perubahan dalam atmosfer ekonomi. Hal ini terbukti bahwa banyak UKM memiliki umur yang pendek dan tidak stabil serta keberadaannya banyak yang tidak mencapai jangka panjang, bahkan lebih sedikit mencapai pertumbuhan substansial.

UKM Anugerah Mina Lestari adalah salah satu unit usaha yang bergerak di bidang pengolahan perikanan. Keberadaan usaha ini memberikan pengaruh secara ekonomi terhadap sektor perikanan, khususnya di Kota Malang. Lokasi UKM Anugerah Mina Lestari sangat strategis, karena berada di tengah-tengah Kota Malang. Produk unggulan yang ditawarkan kepada konsumen adalah aneka olahan dari bandeng (bandeng tanpa duri, bandeng asap, otak-otak bandeng, bandeng millenial, sambal ikan asap, dan lainnya). Produk semacam ini mampu memenuhi kebutuhan protein tubuh dan penting, terutama untuk perkembangan otak. Sehingga produk ini sangat diminati oleh konsumen dan segi rasa yang lebih nikmat dan halal untuk dikonsumsi. Kemudahan dalam memperoleh bahan baku ikan bandeng ini menjadi alasan tersendiri bagi pemilik UKM Anugerah Mina Lestari, karena budidaya ikan bandeng di Indonesia sudah cukup baik. Hal ini sesuai dengan penjelasan dari (WWF-Indonesia, 2014), budidaya ikan bandeng sudah ada sejak abad ke-12, terutama di Pulau Jawa. Sampai saat ini praktek-praktek budidaya ikan bandeng masih banyak yang menerapkan sistem tradisional dan polikultur dengan komoditas budidaya lainnya, seperti rumput laut dan udang windu. Ikan bandeng selain menjadi makanan bernilai gizi, juga telah menjadi komoditas ekspor di Taiwan dan Tiongkok sebagai umpan untuk ikan tuna (Thunnus spp.) dan Cakalang (Katsuwonus pelamis). Budidaya bandeng di Indonesia menunjukkan prospek yang baik, dimana pada tahun 2008 produksi bandeng mencapai 422.086 ton, lebih tinggi dari Filipina yang hanya 349.432 ton. Kemudian produksi meningkat pada tahun 2012 yaitu sebesar 482.930 ton.

Ikan bandeng merupakan ikan herbivore, dibudidayakan dan sering diperjualbelikan di masyarakat. Ketersediaan asam amino lysin dan kandungan protein yang tinggi (Alyani et al., 2016). Hal tersebut merupakan salah satu sebab ikan bandeng merupakan ikan konsumsi yang disukai konsumen. Tekstur dagingnya lembut, sehingga daging disokong oleh duri dalam daging (intermuscular bond). Intermuscullar bone pada ikan bandeng sedikit mengalami osifikasi di myosepta tendon, berbeda dengan intermuscular bone kelompok Cluipeidae yang mengalami osifikasi pada hari 30-60 setelah pemijahan (Chen et al., 2012). Intermuscullar bone ikan bandeng ini dibutuhkan untuk kontraksi otot dan gerakan ikan herbivora pada habitatnya (Nusantari et al., 2017).

Perkembangan industri olahan ikan menuntut pelaku usaha untuk terus meningkatkan daya saing dari produk yang dihasilkannya di pasar global yang kompetitif. Produksi industri pengolahan ikan khususnya bandeng asap dan otak-otak saat ini sebagian besar masih tergantung pada permintaan pasar. Banyaknya UKM yang bergerak dalam bidang yang sama dan memproduksi produk yang sama, mengharuskan UKM dapat bersaing agar usaha yang dijalankan bertahan lama. Pemasaran olahan bandeng untuk saat ini tersebar di wilayah Kota Malang, Batu, Surabaya, Semarang dan Jakarta. Kendala- 
kendala yang umumnya dihadapi oleh para pengusaha kecil menengah atau UKM yang mempengaruhi daya saing adalah: produktivitas rendah, nilai tambah rendah, jumlah investasi yang sangat kecil, jangkauan pasar yang sempit, jaringan usaha sangat terbatas, akses ke sumber modal dan bahan baku terbatas, serta manajemen yang masih belum profesional dan sumberdaya manusia pada umumnya belum memiliki kualitas bersaing untuk maju (Rizal, 2012).

Russell dan Millar (2014) menyatakan bahwa ada lima komponen competitive priority untuk meningkatkan daya saing UKM, yaitu cost, quality, flexibilitas, delivery dan inovation. Muhardi (2007) menyatakan mutu mempunyai beberapa indikator, antara lain; tampilan produk, jangka waktu penerimaan produk, daya tahan produk, kecepatan penyelesaian keluhan konsumen dan kesesuaian produk terhadap spesifikasi desain. Dangayach dan Deshmukh (2001) menyatakan bahwa inovasi bisa menjelaskan bagaimana sebuah perusahaan bisa membuat improvisasi terhadap proses dan produk yang tersedia. UKM Anugrah Mina Lestari di Kota Malang rata-rata sudah memiliki semua komponen tersebut tapi belum efektif dalam menggunakannya.

UKM Anugrah Mina Lestari juga harus mempunyai competitive priority, agar bisa meningkatkan daya saing. Hubeis et al. (2015), strategi untuk meningkatkan UKM berdaya saing dapat dilakukan dengan; meningkatkan kerja sama untuk menjaga kontinuitas ketersediaan bahan baku antar daerah, membangun kawasan industri produk UKM, serta peningkatan peran pemerintah atau swasta dan perguruan tinggi/penelitian pengembangan. Tujuan penelitian ini adalah mendapatkan strategi peningkatan daya saing UKM Anugrah Mina Lestari di Kota Malang.

\section{METODE}

Penelitian ini dilaksanakan di UKM Anugrah Mina Lestari Malang. Teknis analisis data menggunakan metode AHP dengan konsep the house model untuk menentukan strategi peningkatan daya saing
UKM Anugrah Mina Lestari di Kota Malang. Instrumen penelitian dalam penyusunan the house model meliputi merujuk pada hasil penelitian Tsurraya dan Kartika (2015) serta Russell dan Millar (2014), yaitu : produk (kualitas produk, inovasi dan harga), perbaikan SDM (peningkatan prestasi, kemampuan bekerja sama, dan pengembangan keterampilan) serta kelembagaan dan pemasaran (peningkatan jumlah mitra, jumlah bantuan dan akses pasar). Horovitz dan Corboz (2007) menyatakan bahwa konsep the house model merupakan konsep yang dibangun dalam menggambarkan usaha organisasi untuk mengubah mimpi menjadi sebuah tindakan dan dibagi menjadi tiga komponen, yaitu atap sebagai visi dimana visi pada penelitian ini adalah peningkatan daya saing UKM Anugrah Mina Lestari, pilar sebagai kunci utama untuk mencapai visi tersebut, dan pondasi berupa perilaku pendukung.

\section{HASIL DAN PEMBAHASAN}

Paradigma daya saing terus berubah karena perkembangan teknologi yang pesat, kebutuhan konsumen yang tidak stabil dan lingkungan yang tidak dapat diprediksi. Perubahan ini telah menciptakan persaingan yang menantang pengaturan di bidang harga, kualitas, waktu dan inovasi (Lorsuwanrat, 2010). Menggabungkan pengetahuan dan manajemen pengetahuan menjadi penting (Fang et al., 2017; Zhou et al., 2017). Berdasarkan hal tersebut, UKM wajib untuk membuat strategi bisnis yang fleksibel agar dapat terus bersaing di pasar. Permasalahan usaha kecil dan menengah (UKM) di Indonesia pada umumnya relatif sama. Namun penentuan strategi untuk peningkatan daya saing, tetap harus meneliti UKM secara detail dan berkesinambungan agar tercipta suatu solusi dalam memenangkan persaingan yang ada (Meliala et al., 2016). Konsep The house model ini dapat dijadikan rujukan dalam melakukan proses pengembangan untuk mendukung strategi peningkatan daya saing, Hal ini dikarenakan dalam model ini, faktor dan tindakan spesifik dalam 
mendukung penetapan visi dalam jangka waktu tertentu dapat tergambar dengan jelas. Selain itu, tindakan pendukung keberhasilan visi juga tidak dibatasi dalam pengembangannya (Ananda et al., 2016).

Hasil analisis prioritas dan bobot pada tiga variabel diperlihatkan pada Tabel 3, sedangkan pada indikator diperlihatkan pada Tabel 4. Prioritas strategi ditentukan dari alternatif-alternatif terpilih berdasarkan kriteria, sub-kriteria, dan strategi yang dianggap lebih penting terhadap pencapaian sasaran, yang didapatkan berdasarkan pendapat ahli (Evalia, 2015).

Tabel 1. Hasil prioritas dan bobot variabel daya saing

\begin{tabular}{lcc}
\hline Variabel & Bobot & Prioritas \\
\hline Produk & 0,730 & 1 \\
SDM & 0,193 & 2 \\
Kelembagaan dan Pemasaran & 0,077 & 3 \\
\hline
\end{tabular}

Tabel 1 memperlihatkan hasil bobot variabel Daya saing pada produk menjadi prioritas pertama dengan bobot sebesar 0,730. Perbaikan SDM menduduki prioritas kedua dengan bobot sebesar 0,193, sedangkan Kelembagaan pemasaran di prioritas ketiga dengan bobot 0,077 .

Tabel 2. Hasil prioritas dan bobot indikator pada variabel daya saing

\begin{tabular}{lcc}
\hline Indikator & Bobot & Prioritas \\
\hline Kualitas produk & 0,488 & 1 \\
Harga jual & 0,132 & 2 \\
Inovasi & 0,043 & 7 \\
Peningkatan prestasi & 0,019 & 9 \\
Kemampuan bekerja sama & 0,058 & 4 \\
Pengembangan keterampilan & 0,129 & 3 \\
Peningkatan jumlah mitra & 0,023 & 8 \\
Jumlah bantuan pemerintah dan swasta & 0,010 & 10 \\
Memperluas akses pemasaran & 0,051 & 5 \\
Promosi & 0,046 & 6 \\
\hline
\end{tabular}

Tabel 2 memperlihatkan hasil bobot indikator pada variabel daya saing kemampuan dalam memenuhi kualitas produk menjadi prioritas pertama dengan bobot sebesar 0,488. Harga jual menduduki prioritas kedua dengan bobot 0,132 , sedangkan prioritas ketiga dengan bobot sebesar 0,129 merupakan pengembangan keterampilan SDM. Kemampuan bekerja sama antar karyawan di UKM maupun bekerja sama dengan pihak luar UKM bandeng asap merupakan kemampuan yang harus dimiliki oleh pemilik UKM menempati prioritas ke 4 dengan bobot 0,058 dan prioritas ke 5 dengan bobot 0,051 merupakan kemampuan memperluas akses pemasaran. Melakukan kegiatan promosi merupakan prioritas ke 6 dengan bobot 0,046.
Melakukan inovasi baik pada produk maupun proses pengolahan merupakan prioritas ke 7 dengan bobot 0,043. Peningkatan jumlah mitra prioritas ke 8 dengan bobot 0,023, Peningkatan prestasi karyawan maupun UKM prioritas ke 9 dengan bobot 0,019 dan yang merupakan prioritas ke 10 dengan bobot 0,010 adalah jumlah bantuan pemerintah dan swasta yang diperoleh UKM Anugrah Mina Lestari. Hasil penelitian ini sesuai dengan pendapat Gagić et al. (2013) yang menyatakan bahwa kualitas makanan adalah kontributor utama untuk kepuasan pelanggan. Keunggulan produk secara konsisten diidentifikasi sebagai karakteristik produk yang paling penting dalam kesuksesan produk (Healy et al., 2018). 
Tabel 3. Indikator kinerja utama perbaikan daya saing UKM Anugrah Mina Lestari di Kota

\begin{tabular}{|c|c|c|}
\hline Sasaran Strategis & $\begin{array}{l}\text { Pemicu indikator kinerja } \\
\text { utama }\end{array}$ & Hasil indikator kinerja utama \\
\hline \multirow[t]{3}{*}{ Perbaikan Produk } & Kualitas produk & Meningkatnya kualitas produk \\
\hline & Harga produk & $\begin{array}{l}\text { Bersaingnya harga produk dengan para } \\
\text { kompetitor }\end{array}$ \\
\hline & Inovasi & $\begin{array}{l}\text { Mampu melakukan perbaikan proses produksi } \\
\text { sampai kemasan }\end{array}$ \\
\hline \multirow[t]{4}{*}{ Perbaikan SDM } & Peningkatan prestasi & $\begin{array}{l}\text { Meningkatnya prestasi baik personal maupun } \\
\text { lembaga }\end{array}$ \\
\hline & $\begin{array}{l}\text { Kemampuan } \\
\text { sama }\end{array}$ & $\begin{array}{l}\text { Meningkatnya kemampuan kerjasama dengan } \\
\text { karyawan dan pihak luar yang mendukung } \\
\text { perkembangan UKM Anugrah Mina Lestari } \\
\text { dengan baik }\end{array}$ \\
\hline & $\begin{array}{l}\text { Pengembangan } \\
\text { keterampilan }\end{array}$ & $\begin{array}{l}\text { Meningkatnya keterampilan SDM UKM Anugrah } \\
\text { Mina Lestari }\end{array}$ \\
\hline & $\begin{array}{l}\text { Peningkatan jumlah } \\
\text { mitra }\end{array}$ & $\begin{array}{l}\text { Peningkatan jumlah mitra UKM Anugrah Mina } \\
\text { Lestari }\end{array}$ \\
\hline \multirow[t]{3}{*}{$\begin{array}{l}\text { kelembagaan dan } \\
\text { pemasaran }\end{array}$} & $\begin{array}{l}\text { Jumlah bantuan } \\
\text { pemerintah dan swasta }\end{array}$ & $\begin{array}{l}\text { Meningkatnya bantuan pemerintah dan swasta } \\
\text { untuk pengembangan UKM }\end{array}$ \\
\hline & $\begin{array}{l}\text { Memperluas } \\
\text { pemasaran }\end{array}$ & $\begin{array}{l}\text { Meningkatnya wilayah pemasaran bandeng asap } \\
\text { di luar Kota Malang }\end{array}$ \\
\hline & Promosi & $\begin{array}{l}\text { Meningkatnya kemampuan melakukan kegiatan } \\
\text { promosi penjualan produk }\end{array}$ \\
\hline
\end{tabular}

Tabel 3 memperlihatkan hasil Indikator Kinerja Utama pada tingkatan produk adalah meningkatnya kualitas produk, Bersaingnya harga produk dengan para kompetitor, meningkatnya kemampuan memperbaiki proses produksi dan kemasan. Hasil Indikator kinerja utama pada perbaikan SDM adalah meningkatnya keterampilan SDM UKM Anugrah Mina Lestari, meningkatnya prestasi baik personal maupun lembaga,meningkatnya kemampuan bekerja sama dengan karyawan dan pihak luar yang mendukung perkembangan UKM Anugrah Mina Lestari. Penjualan internet telah mengubah bisnis ritel, promosi harga online dan rekomendasi produk harus dipertimbangkan bersama dan ditentukan secara optimal (Jiang et al, 2015). Sumber daya manusia di tingkat UKM dapat mempengaruhi daya saing melalui: kualitas produk dan layanan yang diberikan, kemampuan untuk menghasilkan nilai tambah, praktek manajemen mutu, dan sikap terhadap budaya organisasi baru (Ceptureanu, 2015).

Hasil indikator kinerja utama pada tingkatan kelembagaan dan pemasaran adalah; peningkatan jumlah mitra, meningkatnya bantuan pemerintah dan swasta untuk pengembangan UKM, meningkatnya wilayah pemasaran bandeng asap di luar Kota Malang dan meningkatnya kemampuan melakukan kegiatan promosi penjualan produk. Hasil indikator kinerja utama kemudian dimasukkan ke dalam pilar the house model. Pilar the house model untuk peningkatan daya saing UKM Anugrah Mina Lestari di Kota Malang yang diperlihatkan pada Gambar 1. 


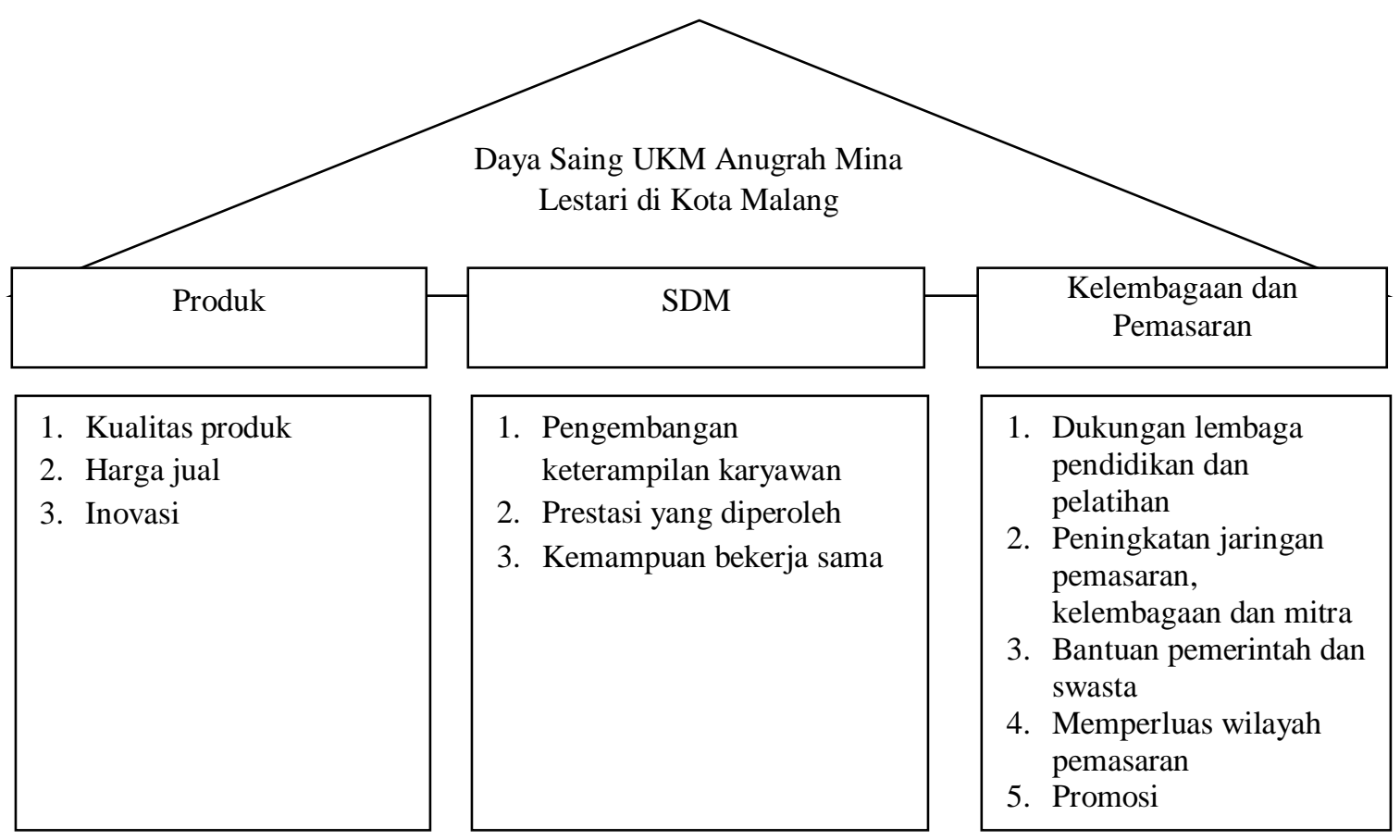

Kebijakan dan regulasi pemerintah dalam memfasilitasi kebutuhan Anugrah Mina Lestari produk, sehingga dapat meningkatkan daya saing produk

Gambar 1. Pilar the house model peningkatan daya saing UKM Anugrah Mina Lestari di Kota Malang

Gambar 1 memperlihatkan bahwa the house model terdiri dari yaitu atap sebagai visi dimana visi pada penelitian ini adalah peningkatan daya saing UKM Anugrah Mina Lestari, pilar sebagai kunci utama untuk mencapai visi tersebut terdiri dari produk, SDM dan kelembagaan pemasaran. Sedangkan pondasi berupa perilaku pendukung yaitu kebijakan dan regulasi pemerintah dalam memfasilitasi kebutuhan UKM Anugrah Mina Lestari, sehingga dapat meningkatkan daya saing produk. Oleh karena itu ada beberapa langkah yang bisa ditawarkan, agar UKM bisa menjaga dan memenangkan persaingan, yaitu: 1) konsisten menjaga kualitas produk, 2) tambahkan daya saing UKM melalui packaging produk yang menarik, 3) berani bersaing dari segi harga dan 4) menjaga loyalitas konsumen.

\section{KESIMPULAN}

Hasil analisis penetapan strategi peningkatan daya saing UKM Anugrah Mina Lestari dengan menggunakan metode the house model menghasilkan bahwa prioritas pertama ada pada perbaikan produk ikan bandeng asap dengan melakukan peningkatan kualitas produk, persaingan harga produk dengan para kompetitor, serta peningkatan kemampuan memperbaiki proses produksi dan kemasan. Prioritas perbaikan yang kedua adalah perbaikan SDM melalui peningkatan keterampilan SDM di UKM Anugrah Mina Lestari, peningkatan prestasi baik personal maupun lembaga, meningkatnya kemampuan bekerja sama dengan karyawan dan pihak luar yang mendukung perkembangan UKM Anugrah Mina Lestari. Prioritas perbaikan yang ketiga adalah kelembagaan dan pemasaran melalui peningkatan jumlah mitra, perluasan akses pemasaran serta promosi.

\section{UCAPAN TERIMAKASIH}

Terima kasih disampaikan sebesarbesarnya kepada Sekolah Tinggi Ilmu Perikanan Malang dan Pemilik UKM Anugrah Mina Lestari. 


\section{DAFTAR PUSTAKA}

Boer, M., Riyanto, M., Kurnia, R., Setyobudiandi, I., Santoso, J., Sukri, N., \& Aziz, K. A. (2020). Estimasi stok suplai kebutuhan bahan baku untuk industri pengolahan ikan. Jurnal Pengolahan Hasil Perikanan Indonesia, 23(1), 158-165.

Chen, J., Bao, B., \& Huang, P. (2012). The ossificational process of the intermuscular bones in Hemibarbus labeo. Journal of Shanghai Ocean University, 21(4), 549-553.

Alyani, F., Ma'ruf, W. F., \& Anggo, A. D. (2016). Pengaruh lama perebusan ikan bandeng (Chanos chanos Forsk) pindang goreng terhadap kandungan lisin dan protein terlarut. Jurnal Pengolahan dan Bioteknologi Hasil Perikanan, 5(1), 88-93.

Ananda, M. S., Sukmawati, A., Syamsun, M., \& Ali, N. A. (2016).Pengembangan model peningkatan kompetensi pekerja domestik Indonesia di Malaysia. Journal of Technology Management, 15(3), 262-278.

Ayandibu, A. O., \& Houghton, J. (2017). The role of Small and Medium Scale Enterprise in local economic development (LED). Journal of Business and Retail Management Research, 11(2), 133-139.

Ceptureanu, S.I. (2015). Competitiveness of SMES. Business Excellence and Management Review, 5(2), 55-67.

Dangayach, G.S., \& Deshmukh, S.G. (2001). Manufacturing strategy, literature review and some issues. International Journal of Operations and Production Management, 21(7), 884-932.

Evalia, N. A. (2015). Strategi pengembangan agroindustri gula semut aren. Jurnal Manajemen \&Agribisnis, 12(1), 57.

Fang, S. C., Wang, M. C., \& Chen, P. C. (2017). The influence of knowledge networks on a firm's innovative performance. Journal of Management \& Organization, 23(1), 22-45. https://doi.org/10.1017/jmo.2016.32
Gagić, S., Tešanović, D. and Jovičić, A. (2013). The vital components of restaurant quality that affect guest satisfaction. Turizam, 17(4), 166-176. https://

doi.org/10.5937/Turizam1304166G

Healy, B., O’Dwyer, M., \& Ledwith, A. (2018). An exploration of product advantage and its antecedents in SMEs. Journal of Small Business and Enterprise Development 24(4), 733752. https://doi.org/10.1108/JSBED06-2017-0206

Horovitz, J., \& Ohlsson-Corboz, A. V. (2007). A dream with a deadline: turning strategy into action. Pearson Education.

Hubeis, M., Purwanto, B., Dewi, F. R., Widyastuti, H., \& Febtyanisa, M. (2015). Strategi pengembangan UMKM pangan yang berdaya saing di Indonesia. In Prosiding Seminar Nasional Hasil-Hasil PPM IPB (Vol. 1, pp. 126-143).

Nusantari, E., Abdul, A., \& Harmain, R. M. (2017). Ikan Bandeng Tanpa Duri (Chanos chanos) sebagai Peluang Bisnis Masyarakat Desa Mootinelo, Kabupaten Gorontalo Utara, Provinsi Gorontalo. Agrokreatif Jurnal Ilmiah Pengabdian kepada Masyarakat 3(1), 78-87.

Idar, R.,\& Mahmood, R. (2011). Entrepreneurial and market orientation relationships to performance: The SME perspective. Interdisciplinary Review of Economics and Management, 1(2), 1-8. Jiang, Y., Shang, J., Liu, Y., \& May, J. (2015). Redesigning promotion strategy for e-commerce competitiveness through pricing and recommendation. International Journal of Production Economics, 167, 257270.

Kalpande, S.D., Gupta, R.C., \& Dandekar, M.D. (2015).Study of SMEs for TQM implementation-SWOT

analysis.International Journal of Engineering and Industrial Management, (2), 167-177. 
Lorsuwanrat, T. (2010). Management tools. Bangkok: Z Probe Printing.

Meliala, A.S., Matondang, N., \& Sari, R. M. (2016). Strategi peningkatan daya saing usaha kecil dan menengah (UKM) berbasis Kaizen. Jurnal Optimasi Sistem Industri, 13(2), 641-664.

Purwidianti, W., \& Rahayu, T. S. M. (2017). Pengaruh faktor internal dan eksternal terhadap kinerja usaha industri kecil dan menengah di Purwokerto Utara. Kinerja, 19(2), 151-161.

Russell, S.N., \& Millar, H. H. (2014). Competitive priorities of manufacturing firms in the Caribbean. IOSR Journal of Business and Management, 16(10), 72-82.

Tsurayya, S., \& Kartika, L. (2015).Kelembagaan dan strategi peningkatan daya saing komoditas cabai kapupaten Garut.Jurnal Manajemen \& Agribisnis, 12(1), 1-13.

Wiesner, R., \& Millett, B. (2012). Strategic approaches in Australian SMEs: deliberate or emergent? Journal of Management and Organization, 18(01), 98-122.

Zhou, D., Kautonen, M., Wang, H., \& Wang, L. (2017). How to interact with knowledge-intensive business services: A multiple case study of small and medium manufacturing enterprises in China. Journal of Management \& Organization, 23(2), 297-318. https://doi.org/10.1017/jmo.2016.23 